\title{
Lung Adenocarcinoma and Squamous Cell Carcinoma in association with Genetic Polymorphisms of GSTs in Slovak Population
}

\author{
A. DZIAN ${ }^{1, *}$, E. HALASOVA ${ }^{2}$, T. MATAKOVA ${ }^{3}$, E. KAVCOVA ${ }^{4}$, M. SMOLAR ${ }^{1}$, D. DOBROTA³ ${ }^{3}$ J. HAMZIK ${ }^{1}$, D. MISTUNA ${ }^{1}$ \\ ${ }^{1}$ Clinic of Surgery, Jessenius Faculty of Medicine and University Hospital in Martin; ${ }^{2}$ Institute of Medical Biology, Jessenius Faculty of Medicine \\ in Martin; ${ }^{3}$ Institute of Medical Biochemisty, Jessenius Faculty of Medicine in Martin; ${ }^{4}$ Clinic of Pneumology and Phthisiology, Jessenius Faculty \\ of Medicine in Martin \\ *Correspondence: anton.dzian@gmail.com
}

Received July 20, 2011 / Accepted September 30, 2011

\begin{abstract}
Slovak Republic belongs to the countries with high incidence of lung cancer. Gene polymorphisms of the glutathione S-transferases (GSTs) may play a role in individual lung cancer susceptibility. In presented case-control study we investigate the incidence of polymorphism of GSTT1, GSTM1, GSTP1 genes and their combinations as possible predictive factors for identification of individuals with increased risk of formation and development of adenocarcinoma (AC) and squamous cell carcinoma (SCC) of lung in Slovak population. The study was conducted on 520 individuals consisting of 118 patients with adenocarcinoma, 112 patients with squamous cell carcinoma and 290 control individuals. GSTT1, GSTM1, GSTP1 gene polymorphisms were assayed by standard PCR and PCR-RFLP technique. The results of this study indicate that the GSTT1 null-genotype and combination GSTT1 null and Ile/Val or Val/Val are associated with increased risk of lung adenocarcinoma. A significant association with 2.13 - fold increased risk was observed between lung adenocarcinoma and GSTT1 null genotype (95\% CI $=1.29-3.51 ; \mathrm{p}=0.004)$. Also it was proved 2.83 times statistically higher risk for development of this histological type of lung cancer $(95 \% \mathrm{CI}=1.34-6.01 ; \mathrm{P}=0.005)$ in combination of GSTT1null and Ile/Val or Val/Val genotypes. GSTT1, GSTM1, GSTP1 polymorphism did not show any significant association with SCC. Our study suggests that genetic make-up in metabolizing genes may increase susceptibility towards lung cancer development.
\end{abstract}

Key words: lung cancer, polymorphism, glutathione S-transferase, adenocarcinoma, squamous cell carcinoma

Lung cancer is a worldwide problem because of its high mortality and morbidity. Slovak Republic belongs to the countries with increasing tendency of its incidence in both sexes. In 2008 the incidence of this illness was in men and women 49.2/100 000 and 10.6/100 000 respectively, while its mortality was 43.4/100 000 and 7.7/100 000 respectively (1).

Approximately $80-90 \%$ of lung carcinomas are associated with the carcinogenetic effect of smoking (2). However, only about $10-15 \%$ of all smokers fall ill on lung cancer. On the other side $10-15 \%$ of all lung carcinomas occur in nonsmokers (3). These facts indicate that there is individual susceptibility to lung carcinogens as well as to development of disorders. Genetic and environmental factors essentially influence the risk of lung cancer genesis, while molecular pathophysiology of genetic-environmental interaction is complex and only partly identified up to now. That is why it is so important to explore, whether individual difference in susceptibility to lung cancer genesis has a genetic background.

Many studies considering the role of biotransformation processes in detoxification or activation of carcinogens show significant interindividual difference in activities of particular biotransformation enzymes, which are both environmental and genetic origin. Despite of that, the particular polymorphism has a relative small influence on the risk of malignant disease genesis. The accumulation and combination of polymorphisms significantly increases this risk of particular individual. Within biotransformation enzymes, the most studied are the polymorphisms of genes of Glutation-S-transferases (GSTs).

Two isoforms of GSTT (GSTT1, GSTT2) metabolize epoxy butane, ethylene oxide, halogen derivatives of methane, methyl bromide, methyl chloride, dichloromethane and diepoxybutane. Deletion in GSTT1 gene leads to genesis of null genotype 
that causes the loss of the enzyme's activity (4). The incidence of null genotype is associated with higher frequentation of malignant diseases $(5-8)$.

GSTM1 catalyzes the conversion of reactive electrophilic intermediates derived from cigarette smoking, such as benzo(a)pyrene- 7,8-diol-9,10-epoxides (BPDE) to less reactive and easier excreted glutathione conjugates (9). Deletion of the gene very often influences both alleles and leads to so called null genotype, which leads to the loss of activity of this izoenzyme. Deletion of GSTM1 is associated with higher sensibility to chemical mutagens $(10,11)$ and with higher frequency of malignant diseases $(12-15)$.

The importance of GSTP enzyme in lung cancer lies in metabolizing of bezo(a)pyrene products and carcinogenetic substances contained in cigarette smoke as bezo(a)pyrene diol epoxide. GSTP1 Ile105Val polymorphism modifies the kinetic properties of coded enzyme $(16,17)$ and some other studies demonstrated higher sensibility for carcinomas in individuals bearing the variant valine allele (18).

In presented case-control study we evaluated the incidence of polymorphism of genes of biotransformation as GSTT1, GSTM1, GSTP1 and their combinations as possible predictive factors of formation and development of adenocarcinoma (AC) and squamous cell carcinoma (SCC) of lung in studied group of Slovak population.

\section{Material and methods}

Studied group. In the case-control study 230 patients with histologically verified adenocarcinoma or squamous cell carcinoma of lungs were included. According to the clinical state, advanced stages of cancer prevailed, what refers on late diagnosis, long silent stage of the disease and non-existing screening of this severe carcinoma. $19.6 \%$ of patients (n 45) were in the time of diagnosis in first stage, $7 \%$ ( $n$ 16) were in second clinical stage, $31.2 \%$ (n 72 ) in third stage. $42.2 \%$ of patients ( $\mathrm{n}$ 97) were in forth clinical stage. We created two groups from the patients according to the histological type of carcinoma: patients with adenocarcinoma in number of 118 and patients with squamous cell carcinoma in number of 112 . In control group 290 healthy volunteers and patients hospitalized for non-cancer disease were included. The controls were recruited in parallel with the cancer cases. More accurate demographic characteristics of the file including smoking status are displayed in table 1. All included objects were from Slovak population only Caucasians.

Determination of GSTT1, GSTM1 and GSTP1 genotypes. Genomic DNAs were extracted from leukocytes in peripheral venous blood by conventional procedures (19). Genetic polymorphisms of GSTM1 and GSTT1 are determined at the same time by application of polymerase chain reaction (PCR) in one reaction with gene for $\beta$-globin, which has the function of inner positive control. For determination of GSTM1 primer according to Chen et al. 5'-GAA CTC CCT GAA AAG CTA AAG C-3' and 5'-GTT GGG CTC AAA TAT ACG GTC G-3' is used (20), for GSTT1 primer described by To-Figueras et al. 5' CAG ATC TC-3' and 5' -TCA CCG GAT CAT GGC CAG CA-3' (21). $\beta$-actin fragment is amplified parallely as control of amplification (primer $5^{\prime}$-CAA CTT CAT CCA CGT TCA CC-3' and 5'-GAA GAG CCA AGG ACA GGT AC-3'). Polymorphism of GSTP1 gene in codon 105, where adenine is changed for guanine (what leads to the change of amino acid isoleucine - Ile for amino acid valine - Val), was detected by PCR-RFLP (Restriction Fragment Length Polymorphism) method. GSTP1 was analyzed using the primers 5' -ACC CCA GGG CTC TAT GGG AA-3' and 5'-TGA GGG CAC AAG AAG CCC CT-3' and the PCR products were digested by the restriction endonuclease $A L W 26 I$ to cut the mutated allele.

Statistical analysis. Associations between the GSTM1, GSTT1 and GSTP1 polymorphisms and the risk of lung AC and SCC were estimated using odds ratios (ORs) and 95\% confidence intervals (95\% CIs). Differences in genotype distributions in cancer cases and the controls were compared

Table 1. Demographic characteristics of the lung AC and SCC cases and controls

\begin{tabular}{|c|c|c|c|c|c|}
\hline Characteristics & $\begin{array}{l}\text { Cases Adenocarcinoma } \\
(\mathrm{n}=118)\end{array}$ & $\begin{array}{c}\text { Cases } \\
\begin{array}{c}\text { Squamous cell carcinoma } \\
(\mathrm{n}=112)\end{array} \\
\end{array}$ & $\begin{array}{l}\text { Controls } \\
(\mathrm{n}=290)\end{array}$ & $p$ value $A C$ & p value SCC \\
\hline \multicolumn{6}{|l|}{ Gender } \\
\hline Male (n) & 88 & 95 & 224 & $0.66^{\mathrm{a}}$ & $0.07^{\mathrm{a}}$ \\
\hline Female (n) & 30 & 17 & 66 & & \\
\hline \multicolumn{6}{|l|}{ Age } \\
\hline Median (years) & 62 & 63 & 59 & & \\
\hline Range (years) & $48-85$ & $47-88$ & $51-78$ & & \\
\hline Mean (SD) & $62.5 \pm 7.6$ & $63.7 \pm 9$ & $62.2 \pm 7$ & $0.7^{\mathrm{b}}$ & $0.07^{\mathrm{b}}$ \\
\hline \multicolumn{6}{|l|}{ Smoking status } \\
\hline Non-smokers & $40(33.9 \%)$ & $11(9.8 \%)$ & $96(33.1 \%)$ & & \\
\hline Smokers & $78(66.1 \%)$ & $101(90.2 \%)$ & $194(66.9 \%)$ & $0.9692^{a}$ & $<0.0001^{\mathrm{a}}$ \\
\hline
\end{tabular}

a Chi²-test

b t-test 
for statistical significance using the $\mathrm{Chi}^{2}$-test. Student's t-test was used to determine differences in means of age between cancer cases and controls. Bonferroni correction was taken into consideration between different combinations of GST genopytes and the risk of lung cancer because of the multiple comparisons carried out in this study. According to this correction p-value $<0.017(0.05 / 3)$ for combinations of two polymorphism and $\mathrm{p}$-value $<0.007(0.05 / 7)$ for combinations of three polymorphism was considered statistically significant. Gene-smoking interactions adjusted for age, gender and relevant genotypes were not analyzed due to the small number of patients.

\section{Results}

The distributions for gender and age among cases (AC and SCC separately) and controls were not statistically different (tab. 1). The distribution of smokers was not significantly different between cases with AC (66.1\%) and controls (66.9\%). The distribution of smokers was significantly different between cases with SCC (90.2\%) and controls (66.9\%), what indicates on the main etiological factor in genesis of this histological type of carcinoma. The distribution of GSTT1, GSTM1 and GSTP1 genotypes and their respective ORs for lung AC and SCC are presented in table 2 and 3 separately.

The distribution of GST genotypes among controls in this study was found to be similar to those reported for Caucasians.

The frequencies of the GSTT1 null genotype were significantly elevated in cases with AC (29.6\%) when compared with the controls $(16.6 \%)\left(\chi^{2}=8.1 ; p=0.004\right)$. The adjusted ORs of lung AC for the GSTT1 null genotype was 2.13 (95\% $\mathrm{CI}=1.29-3.51)(\mathrm{tab} .2)$. This association was not observed in SCC. Elevated frequencies of the GSTT1 null in cases with SCC (21.5\%) compared with the controls (16.6\%) were not significant. The adjusted ORs of lung SCC for the GSTT1 null genotype was minimally elevated 1.38 (tab. 4).
The GSTM1 distributions did not show significant differences between the controls (55.2\%) and AC (54.2\%) and SCC (58.9\%) patients (tab. 2, 4).

The frequencies of three GSTP1 genotypes among controls (Ile/Ile, 52.8; Ile/Val, 39.7; and Val/Val, 7.5\%) were not different from those expected from the Hardy-Weinberg equilibrium. Frequencies of the GSTP1 homozygote (Val/Val) were elevated in cases with AC and SCC (11.0\% and 9.8\%, respectively) when compared to the controls ( $7.5 \%)$, but the difference was not significant.

We did not find statistically significant associations between the risk of AC or SCC and any of the GSTM1 and GSTP1 polymorphisms.

The ORs for combination of GSTM1, GSTT1 and GSTP1 genotypes for lung AC and SCC are shown in table 3, 5 respectively. In AC it was found 2.83 times statistically higher risk for development of this histological type of lung cancer ( $95 \%$ $\mathrm{CI}=1.34-6.01 ; \mathrm{P}=0.005)$ in combination of GSTT1null and Ile/Val or $\mathrm{Val} / \mathrm{Val}$ genotypes. The other combined genotypes were not significantly associated with higher risk than the separate genotypes. We did not observe any significant interactions between combinations of genetic polymorphisms of GSTT1, GSTM1, GSTP1 and the SCC cases.

\section{Discussion}

Molecular - epidemiologic studies focus on investigation of enzymes of the first and second phase of xenobiotic metabolism. The extent of association between human GSTM1, GSTT1 or GSTP1 genetic polymorphisms and lung cancer risk is discussed controversially (22). It is most likely because it is about genes with low penetration ability and moreover in observed control groups composed from healthy individuals there was also found difference in frequency of GST polymorphisms among races and also a smaller heterogenity was found in Caucasian population from different countries (23). The distribution of GST genotypes among controls

Table 2. Distribution of genotype and frequency of alleles in polymorphisms of GSTP1, GSTT1 and GSTP1 in patients with AC.

\begin{tabular}{|c|c|c|c|c|c|c|}
\hline Genotypes & Cases n(\%) & Controls n(\%) & ORs & $95 \% \mathrm{CI}$ & p value & $x$ \\
\hline \multicolumn{7}{|l|}{ GSTT1 } \\
\hline present & $83(70.4 \%)$ & $242(83.4 \%)$ & ref. & & & \\
\hline null & $35(29.6 \%)$ & $48(16.6 \%)$ & 2.13 & $1.29-3.51$ & 0.004 & 8.10 \\
\hline \multicolumn{7}{|l|}{ GSTM1 } \\
\hline positive & $54(45.8 \%)$ & $130(44.8 \%)$ & ref. & & & \\
\hline null & $64(54.2 \%)$ & $160(55.2 \%)$ & 0.96 & $0.63-1.48$ & 0.95 & 0.004 \\
\hline \multicolumn{7}{|l|}{ GSTP1 } \\
\hline Ile/Ile & $59(50 \%)$ & $153(52.8 \%)$ & ref. & & & \\
\hline Ile/Val & $46(39 \%)$ & $115(39.7 \%)$ & 1.04 & $0.66-1.64$ & 0.97 & 0.002 \\
\hline $\mathrm{Val} / \mathrm{Val}$ & $13(11 \%)$ & $22(7.5 \%)$ & 1.53 & $0.72-3.24$ & 0.36 & 0.85 \\
\hline${ }^{*} \mathrm{Val}$ & $59(50 \%)$ & $137(47.2 \%)$ & 1.12 & $0.73-1.71$ & 0.69 & 0.16 \\
\hline
\end{tabular}

${ }^{\star}$ Ile/Val or $\mathrm{Val} / \mathrm{Val}$

Statistically significant differences between cases and controls are shown in bold. 
Table 3. Mutual combinations of genotypes of GSTP1, GSTT1 and GSTP1 and their association with adenocarcinoma.

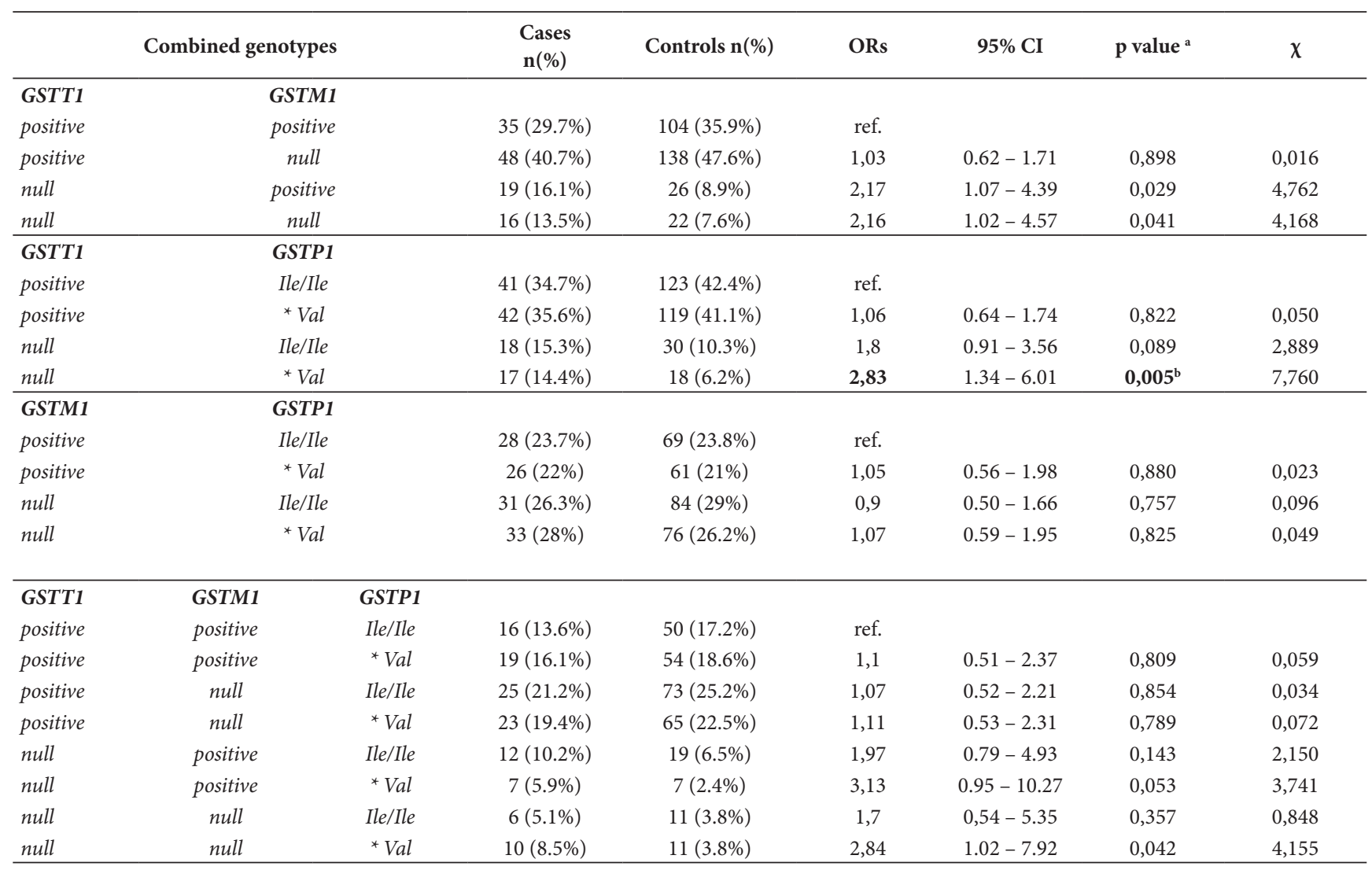

* Ile/Val or $\mathrm{Val} / \mathrm{Val}$

Statistically significant differences between cases and controls are shown in bold.

a Corrected for multiple testing.

b Differences statistically significant after Bonferroni correction as p-values are $<0.017$.

Table 4. Distribution of genotypes and frequency of alleles in polymorphisms of GSTP1, GSTT1 and GSTP1 in patients with SCC.

\begin{tabular}{|c|c|c|c|c|c|c|}
\hline Genotypes & Cases n(\%) & Controls n(\%) & ORs & $95 \% \mathrm{CI}$ & p value & $\chi$ \\
\hline \multicolumn{7}{|l|}{ GSTT1 } \\
\hline positive & $88(78.5 \%)$ & $242(83.4 \%)$ & ref. & & & \\
\hline null & $24(21.5 \%)$ & $48(16.6 \%)$ & 1.38 & $0.80-2.38$ & 0.32 & 0.99 \\
\hline \multicolumn{7}{|l|}{ GSTM1 } \\
\hline positive & $46(41.1 \%)$ & $130(44.8 \%)$ & ref. & & & \\
\hline null & $66(58.9 \%)$ & $160(55.2 \%)$ & 1.17 & $0.75-1.81$ & 0.57 & 0.32 \\
\hline \multicolumn{7}{|l|}{ GSTP1 } \\
\hline Ile/Ile & $56(50 \%)$ & $153(52.8 \%)$ & ref. & & & \\
\hline Ile/Val & $45(40.2 \%)$ & $115(39.7 \%)$ & 1.07 & $0.67-1.7$ & 0.87 & 0.03 \\
\hline $\mathrm{Val} / \mathrm{Val}$ & $11(9.8 \%)$ & $22(7.5 \%)$ & 1.37 & $0.62-3.0$ & 0.57 & 0.33 \\
\hline${ }^{*} \mathrm{Val}$ & $56(50 \%)$ & $137(47.2 \%)$ & 1.12 & $0.72-1.73$ & 0.7 & 0.15 \\
\hline
\end{tabular}

${ }^{*}$ Ile/Val or $\mathrm{Val} / \mathrm{Val}$

in this study was found to be similar to those reported for Caucasians.

Different histological subtypes of lung cancer particularly may also be related to respective exposures or factors and that is why they need to be analyzed separately (24). Therefore we studied lung cancer patients and controls to estimate the association of the GSTM1, GSTT1 or GSTP1-polymorphisms in relation to two most frequent histological types of lung cancer. 
Table 5. Mutual combinations of genotypes of GSTP1, GSTT1 and GSTP1 and their association with SCC.

\begin{tabular}{|c|c|c|c|c|c|c|c|c|}
\hline \multicolumn{3}{|c|}{ Combined genotypes } & \multirow[t]{2}{*}{$\begin{array}{c}\text { Cases } \\
\mathbf{n}(\%)\end{array}$} & \multirow[t]{2}{*}{ Controls n(\%) } & \multirow[t]{2}{*}{ ORs } & \multirow[t]{2}{*}{$95 \% \mathrm{CI}$} & \multirow[t]{2}{*}{ p value ${ }^{a}$} & \multirow[t]{2}{*}{$\chi$} \\
\hline GSTT1 & & GSTM1 & & & & & & \\
\hline positive & & positive & $34(30.4 \%)$ & $104(35.9 \%)$ & ref. & & & \\
\hline positive & & null & $54(48.2 \%)$ & $138(47.6 \%)$ & 1,17 & $0.73-1.97$ & 0,480 & 0,499 \\
\hline null & & positive & $12(10.7 \%)$ & $26(8.9 \%)$ & 1,41 & $0.64-3.1$ & 0,389 & 0,744 \\
\hline null & & null & $12(10.7 \%)$ & $22(7.6 \%)$ & 1,67 & $0.75-3.72$ & 0,209 & 1,581 \\
\hline GSTT1 & & GSTP1 & & & & & & \\
\hline positive & & Ile/Ile & $44(39.3 \%)$ & $123(42.4 \%)$ & ref. & & & \\
\hline positive & & ${ }^{*} \mathrm{Val}$ & $44(39.3 \%)$ & $119(41.1 \%)$ & 1,04 & $0.63-1.68$ & 0,894 & 0,018 \\
\hline null & & Ile/Ile & $12(10.7 \%)$ & $30(10.3 \%)$ & 1,12 & $0.53-2.37$ & 0,771 & 0,085 \\
\hline null & & ${ }^{*} \mathrm{Val}$ & $12(10.7 \%)$ & $18(6.2 \%)$ & 1,86 & $0.83-4.18$ & 0,127 & 2,330 \\
\hline GSTM1 & & GSTP1 & & & & & & \\
\hline positive & & Ile/Ile & $23(20.5 \%)$ & $69(23.8 \%)$ & ref. & & & \\
\hline positive & & ${ }^{*} \mathrm{Val}$ & $23(20.5 \%)$ & $61(21 \%)$ & 1,13 & $0.58-2.22$ & 0,720 & 0,129 \\
\hline null & & Ile/Ile & $33(29.5 \%)$ & $84(29 \%)$ & 1,18 & $0.63-2.19$ & 0,604 & 0,270 \\
\hline null & & $*$ Val & $33(29.5 \%)$ & $76(26.2 \%)$ & 1,3 & $0.7-2.43$ & 0,406 & 0,691 \\
\hline GSTT1 & GSTM1 & GSTP1 & & & & & & \\
\hline positive & positive & Ile/Ile & $17(15.1 \%)$ & $50(17.2 \%)$ & ref. & & & \\
\hline positive & positive & ${ }^{*} \mathrm{Val}$ & $17(15.1 \%)$ & $54(18.6 \%)$ & 0,93 & $0.43-2.01$ & 0,846 & 0,038 \\
\hline positive & null & Ile/Ile & $27(24.1 \%)$ & $73(25.2 \%)$ & 1,09 & $0.54-2.2$ & 0,815 & 0,055 \\
\hline positive & null & ${ }^{*}$ Val & $27(24.1 \%)$ & $65(22.5 \%)$ & 1,22 & $0.6-2.49$ & 0,580 & 0,306 \\
\hline null & positive & Ile/Ile & $6(5.4 \%)$ & $19(6.5 \%)$ & 0,93 & $0.32-2.71$ & 0,892 & 0,018 \\
\hline null & positive & ${ }^{*} \mathrm{Val}$ & $6(5.4 \%)$ & $7(2.4 \%)$ & 2,52 & $0.74-8.55$ & 0,130 & 2,295 \\
\hline null & null & Ile/Ile & $6(5.4 \%)$ & $11(3.8 \%)$ & 1,6 & $0.51-5$ & 0,413 & 0,671 \\
\hline null & null & ${ }^{*} \mathrm{Val}$ & $6(5.4 \%)$ & $11(3.8 \%)$ & 1,6 & $0.51-5$ & 0,413 & 0,671 \\
\hline
\end{tabular}

${ }^{*} \mathrm{Ile} / \mathrm{Val}$ or $\mathrm{Val} / \mathrm{Val}$

a Corrected for multiple testing.

There was a change in occurrence of histological types of lung carcinomas in last two decades and adenocarcinoma became the most frequent $(30-40 \%$ of all). In past squamous cell carcinoma dominated. Percentual proportion of adenocarcinomas is higher in Asian population than in North America or Europe. Adenocarcinoma dominates in young people, women of every age, non-smokers and ex-smokers who didn't smoke for longer time. There is no satisfying explanation for this change of histological type. A possible cause can be the change of compounds of inhaled carcinogens and filtration of tobacco smoke, increasing production of volatile nitrosamines and their accumulation in terminal bronchioles and alveols when deeper inhalation (25). The studies describe various genetic and epigenetic alterations in tumor cells of lung cancer, which differ according to various histological types and thus suggest different pathogenic ways of each type of lung cancer development (26). That is why some of the polymorphisms of single nucleotide could be associated with different types of lung cancer.

Previous studies did not find any significant effect of the GSTT1 null genotype on lung cancer (27-33). Two of the studies by Saarikoski et al. and Stucker et al. found that the GSTT1 null genotype did not elevate the risk with neither lung AC or SCC $(33,34)$. So far Spitz et al. have shown statistically significant risk with $\mathrm{OR}=1.41$ for GSTT1 null genotype (35). Also the study on Chinese (31) and Indian study (36) confirm the association between GSTT1 null genotype and lung cancer. A recent study in Japan provided evidence that the GSTT1 null genotype is a risk factor for lung AC development and that the genetic factors for susceptibility to AC differ from those for SCC (37). Sorensen et al. found a strong effect of the GSTT1 polymorphism for SCC, suggesting that the GSTT1 enzyme may be important in preventing the development of this type of lung cancer (38). We found that in the Slovak population the GSTT1 null-genotype was significantly associated only with lung AC cancer risk (OR $=2.13$ ), but not with SCC.

According to the published data the association of GSTM1 polymorphism with the lung cancer formation is controversial. A study by Woodson et al. in Caucasians reported a significant association of lung AC with the GSTM1 null genotype (39). Mc. Williams et al. in their meta-analysis mention that GSTM1 null genotype is a moderate risk factor for lung cancer formation with $\mathrm{OR}=1.41$ (95\%CI 1.23-1.61), while this association is more significant in Japanese population $(\mathrm{OR}=1.6 ; 95 \% \mathrm{CI}=$ $1.2-2.1)$ than in Caucasian population $(\mathrm{OR}=1.2 ; 95 \% \mathrm{CI}=$ 
1.0-1.4). According to this study $59.1 \%$ of patients with lung AC are carriers of GSTM1 null genotype and it was provided non-significantly increased risk in patients with $\mathrm{AC}, \mathrm{OR}=$ 1.449 (40). Next meta-analysis by Houlston et al. of genotype studies has shown 1.13 times higher risk of lung cancer formation $(95 \% \mathrm{CI}=1.04-1.25)$ (41). Other meta-analysis published by Benhamou et al. did not confirm statistically significant relationship between carriers of GSTM1 null genotype and susceptibility to lung cancer (22). The analysis of 14 case-control studies on Caucasian population did not find increased risk of GSTM1 null genotype for lung cancer (42). Another meta-analysis found the strongest effect of the GSTM1 polymorphism for squamous and small cell carcinomas. The last meta-analysis from Carlsten et al. observed modest effect of the GSTM1 null variant on lung cancer risk (43). In our population we did not find increased risk for AC or SCC formation in patients with GSTM1 null genotype.

The most of the studies have been monitoring the association of GSTP1 polymorphism in codon 105 and lung cancer did not prove significant risk of GSTP1 Val genotype (28, $33,44-50)$. Not even in our study was found significant association between polymorphism of GSTP1 and AC or SCC formation.

Some studies have suggested that subjects with a defect genotype in 2 GST genes are at higher risk of lung cancer formation than subjects with no or only 1 defect of GST gene (33). More studies evaluate the combined effects of GSTM1 and GSTT1, GSTP1. When following the combinations of GSTT1 and GSTM1 genotypes, the most of the studies did not find any association $(21,30,51)$. Other studies have shown: significant association of combination of both null genotypes of GSTM1 and GSTT1 with the occurrence of SCC (33); significantly increased risk for formation of lung cancer in presence of both null polymorphisms of GSTM1 and $\operatorname{GSTT1}(28,31)$. Increased risk of lung cancer development was found in Japanese men smokers at the age of 50-69 years with combination of genotypes GSTP1 and GSTM1 null (47); increased risk in individuals from Caucasian population with the combination of genotype GSTP1 Val/Val and GSTM1 null (48) and combination of genotypes GSTP1 $\mathrm{Val} / \mathrm{Val}$ and GSTM1 null represents 6.9 times higher risk for lung cancer development (34). GSTT1 null genotype has in our study shown to be a strong factor increasing the risk of $\mathrm{AC}$ development. For AC we have not find the risk combination of both null GSTT1 and GSTM1 genotypes. Statistically significant risk was presented by the combination GSTT1 null with GSTP1Ile/Val or Val/Val (OR = 2.83). No significant association of combinations of single genotypes of GST and lung SCC was observed.

In conclusion, the results of this study indicate that the GSTT1 null-genotype and combination GSTT1 null and GSTP1 Ile/Val or $\mathrm{Val} / \mathrm{Val}$ are associated with the elevated risk of lung adenocarcinoma in Slovak population. GSTT1, GSTM1, GSTP1 polymorphism are not associated with SCC. Our study suggests that genetic make-up in metabolizing genes may increase susceptibility towards lung cancer development. They should be studied in association with other factors as race, ethnic, age, smoking, exposition to xenobiotics and histological type.

Acknowledgements: This work was supported by project "CENTER OF TRANSLATIONAL MEDICINE" co-financed from EU sources and European Regional Development Fund ; by grants of the Ministry of Education AV 4/0013/06, VEGA 1/3397/06; Grant of Commenius University UK/48/2010 and Europian Social Found.

\section{References}

[1] FERLAY J, SHIN HR, BRAY F, FORMAN D, MATHERS C et al. GLOBOCAN 2008 Cancer Incidence and Mortality Worldwide: IARC CancerBase No. 10, Lyon. 2010; Internet: http://globocan.iarc.fr

[2] RISCH A, PLASS C Lung cancer epigenesist and genetics. Int J Cancer, 2008; 123: 1-7. http://dx.doi.org/10.1002/ijc.23605

[3] CHO WC Cancer research on non-small cell lung cancer in smokers and non-smokers: snapshots from the AACR annual meeting 2009. Cancer Biol Ther, 2009; 8: 1309-12. http://dx.doi.org/10.4161/cbt.8.14.9195

[4] NTAIS C, POLYCARPOU A, IOANNIDIS JPA Association of GSTM1, GSTT1, and GSTP1 Gene Polymorphisms with the Risk of Prostate Cancer: A Meta-analysis Cancer Epidemiol Biomarkers Prev, 2005; 14: 176-181.

[5] WANG Y, YANG H, LI L, WANG H Glutathione S-transferase T1 gene deletion polymorphism and lung cancer risk in Chinese population: a meta-analysis. Cancer Epidemiol, 2010; 34: 593-7. http://dx.doi.org/10.1016/i.canep.2010.05.008

[6] MARTINEZ C, MARTIN F, FERNANDEZ JM, GARCIAMARTIN E, SASTRE J et al. Glutathione S-transferases mu1, theta1, pi1, alpha1 and mu3 genetic polymorphisms and the risk of colorectal and gastric cancers in humans. Pharmacogenomics, 2006; 7: 711-8. http://dx.doi.org/10.2217/ 14622416.7.5.711

[7] SANYAL S, FESTA F, SAKANO S, ZHANG Z, STEINECK $\mathrm{G}$ et al. Polymorphisms in DNA repair and metabolic genes in bladder cancer. Carcinogenesis, 2004; 25: 729-34. http:// dx.doi.org/10.1093/carcin/bgh058

[8] QIAN J, JING J, JIN G, WANG H, WANG Y et al. Association between polymorphisms in the GSTA4 gene and risk of lung cancer: a case-control study in a Southeastern Chinese population. Mol Carcinog, 2009; 48: 253-9. http://dx.doi. org $/ 10.1002 / \mathrm{mc} .20478$

[9] STRANGE RC, SPITERI MA, RAMACHANDRAN S, FRYER AA Glutathione-Stransferase family of enzymes. Mutat Res 2001; 482: 21-6. http://dx.doi.org/10.1016/S00275107(01)00206-8

[10] STRANGE RC, MATHAROO B, FAULDER CG,JONES P, COTTON W et al. The human glutathione S-transferase: A case-control study of the incidence of the GST1 0 phenotype in patients with adenocarcinoma. Carcinogenesis, 1991; 12: 25-28. http://dx.doi.org/10.1093/carcin/12.1.25

[11] VAN POPPEL G, DE VOGEL N, VAN BALDEREN PJ, KOK FJ Increased cytogenetic damage in smokers deficient in 
glutathione S-transferase isozyme mu. Carcinogenesis, 1992; 13: 303-305. http://dx.doi.org/10.1093/carcin/13.2.303

[12] NOSHEEN M, ISHRAT M, MALIK FA, BAIG RM, KAYANI MA Association of GSTM1 and GSTT1 gene deletions with risk of head and neck cancer in Pakistan: a case control study. Asian Pac J Cancer Prev, 2010; 11: 881-5.

[13] ECONOMOPOULOS KP, CHOUSSEIN S, VLAHOS NF, SERGENTANIS TN GSTM1 polymorphism, GSTT1 polymorphism, and cervical cancer risk: a meta-analysis. Int J Gynecol Cancer, 2010; 20: 1576-80.

[14] UEDA M, TOJI E, NUNOBIKI O, SATO N, IZUMA S et al. Germline polymorphisms of glutathione-S-transferase GSTM1, GSTT1 and p53 codon 72 in cervical carcinogenesis. Hum Cell, 2010; 23: 119-25. http://dx.doi.org/10.1111/j.17490774.2010.00089.x

[15] CHEN B, ZHOU Y, YANG P, WU XT Glutathione S-transferase M1 gene polymorphism and gastric cancer risk: an updated analysis. Arch Med Res, 2010; 41: 558-66. http:// dx.doi.org/10.1016/j.arcmed.2010.09.003

[16] HU X, JI X, SRIVASTAVA SK, XIA H, AWASTHI S et al. Mechanism of differential catalytic efficiency of two polymorphic forms of human glutathione S-transferase P1-1 in the glutathione conjugation of carcinogenic diol epoxide of chrysene. Arch Biochem Biophys., 1997; 345: 32-8. http:// dx.doi.org/10.1006/abbi.1997.0269

[17] ZIMNIAK P, NANDURI B, PIKULA S, BANDOROWICZPIKULA J, SINGHAL SS et al. Naturally occurring human glutathione S-transferase GSTP1-1 isoforms with isoleucine and valine in position 104 differ in enzymic properties. Eur J Biochem., 1994; 224: 893-9. http://dx.doi.org/10.1111/j.14321033.1994.00893.x

[18] SAFARINEJAD MR, SHAFIEI N, SAFARINEJAD SH Glutathione S-transferase gene polymorphisms (GSTM1, GSTT1, GSTP1) and prostate cancer: a case-control study in Tehran, Iran. Prostate Cancer Prostatic Dis, 2011; 14: 105-13. http:// dx.doi.org/10.1038/pcan.2010.54

[19] BLIN N, STAFFORD DW A general method for isolation of high molecular weight DNA from eukaryotes, Nucleic Acids Res, 1976; 3: 32303-2308.

[20] CHEN CL, LIU Q, RELLING MV Simultaneous characterization of glutathione S-transferase M1 and T1 polymorphisms by polymerase chain reaction in American whites and blacks. Pharmacogenetics, 1996; 6: 187-191. http://dx.doi. org/10.1097/00008571-199604000-00005

[21] TO-FIGUERAS J, GENE M, GOMEZ-CATALAN J, GALAN MC, FUENTES $M$ et al. Glutathione S-transferase M1 (GSTM1) and T1 (GSTT1) polymorphisms and lung cancer risk among Northwestern Mediterraneans. Carcinogenesis 1997; 18: 1529-1533. http://dx.doi.org/ $\underline{10.1093 / \mathrm{carcin} / 18.8 .1529}$

[22] BENHAMOU S, LEE WJ, ALEXANDRIE AK, BOFETTA P, BOUCHARDY C et al. Meta-and pooled analyses of the effect of glutathione S-transferase M1 polymorphisms and smoking on lung cancer risk. Carcinogenesis 2002; 23: 1334-1350. http://dx.doi.org/10.1093/carcin/23.8.1343

[23] GARTE S, GASPARI L, ALEXANDRIE AK, AMBROSONE C, AUTRUP $\mathrm{H}$ et al. Metabolic gene polymorphism frequencies in control populations. Cancer Epidemiol Biomarkers Prev 2001; 10: 1239-48.

[24] SOBTI RC, KAUR P, KAUR S, JANMEJA AK, JINDAL SK et al. Combined effect of GSTM1, GSTT1 and GSTP1 polymorphisms on histological subtypes of lung cancer. Biomarkers, 2008; 13: 282-95. http://dx.doi.org/10.1080/ 13547500701843437

[25] PASS HI, CARBONE DP, JOHNSON DH, MINNA JD, TURRISI AT Lung Cancer: Principles \& Practice, 3rd Edition, Lippincott Williams \& Wilkins, 2005.

[26] TOYOOKA S, TOKUMO M, SHIGEMATSU H, MATSUO $\mathrm{K}, \mathrm{ASANO} \mathrm{H}$ et al. Mutational and epigenetic evidence for independent pathways for lung adenocarcinomas arising in smokers and never smokers. Cancer Res, 2006; 66: 1371-5. http://dx.doi.org/10.1158/0008-5472.CAN-05-2625

[27] LAN Q, HE X, COSTA DJ, TIAN L, ROTHMAN N et al. Indoor coal combustion emissions, GSTM1 and GSTT1 genotypes, and lung cancer risk: a case-control study in Xuan Wei, China. Cancer Epidemiol Biomark Prev 2000; 9: 605-608.

[29] KIYOHARA C, YAMAMURA K, NAKANISHI Y, TAKAYAMA K, HARA N Polymorphism in GSTM1, GSTT1, and GSTP1 and susceptibility to lung cancer in a Japanese population, Asian Pacific J Cancer Prev 2000; 1: 293-298.

[29] LONDON SJ, YUAN JM, CHUNG FL, GAO YT, COETZEE GA et al. Isothiocyanates, glutathione S-transferase M1 and T1 polymorphisms, and lung-cancer risk: a prospective study of men in Shanghai, China. Lancet 2000; 356: 724-729. http:// dx.doi.org/10.1016/S0140-6736(00)02631-3

[30] DEAKIN M, ELDER J, HENDRICKSE C, PECKHAM D, BALDWIN D et al. Glutathione Stransferase GSTT1 genotypes and susceptibility to cancer: studies of interactions with GSTM1 in lung, oral, gastric and colorectal cancers. Carcinogenesis 1996; 17: 881-884. http://dx.doi.org/10.1093/ carcin/17.4.881

[31] JIN Y, XU H, ZHANG C, KONG Y, HOU Y et al. Combined effects of cigarette smoking, gene polymorphisms and methylations of tumor suppressor genes on non small cell lung cancer: a hospital-based case-control study in China. BMC Cancer, 2010; 10: 422. http://dx.doi.org/10.1186/1471-2407$\underline{10-422}$

[32] JOURENKOVA N, REINIKAINEN M, BOUCHARDY C, HUSGAFVEL-PURSIAINEN K, DAYER P et al. Effects of glutathione S-transferases GSTM1 and GSTT1 genotypes on lung cancer risk in smokers. Pharmacogenetics 1997; 7: 515-518. http://dx.doi.org/10.1097/00008571-199712000$\underline{00010}$

[33] SAARIKOSKI ST, VOHO A, REINIKAINEN M, ANTTILA S, KARJALAINEN A et al. Combined effect of polymorphic GST genes on individual susceptibility to lung cancer. Int J Cancer 1998; 77: 516-521. http://dx.doi.org/10.1002/(SICI)10970215(19980812)77:4<516::AID-IJC7>3.0.CO;2-X

[34] STUCKER I, HIRVONEN A, DE WAZIERS I, CABELGUENNE A, MITRUNEN K et al. Genetic polymorphisms of glutathione Stransferases as modulators of lung cancer susceptibility. Carcinogenesis 2002; 23: 1475-1481. http://dx.doi. org/10.1093/carcin/23.9.1475 
[35] SPITZ MR, DUPHORNE CM, DETRY MA, PILLOE PC, AMOS CI et al. Dietary intake of isothiocyanates: evidence of a joint effect glutathione S-transferase polymorphism in lung cancer risk. Cancer Epidemiol Biomark Prev 2000; 9: 1017-1020.

[36] SREEJA L, SYAMALA V, HARIHARAN S, SYAMALA VS, RAVEENDRAN PB et al. Glutathione S-transferase M1, T1 and $\mathrm{P} 1$ polymorphisms: susceptibility and outcome in lung cancer patients. J Exp Ther Oncol 2008; 7: 73-85.

[37] SUNAGA N, KOHNO T, YANAGITANI N, SUGIMURA H, KUNITOH H et al. Contribution of the NQO1 and GSTT1 polymorphisms to lung adenocarcinoma susceptibility, Cancer Epidemiol Biomarkers Prev 2002; 11: 730-738.

[38] SORENSEN M, AUTRUP H, TJRNNELAND A, OVERVAD K, RAASCHOU-NIELSEN O Glutathione S-transferase T1 null-genotype is associated with an increased risk of lung cancer. Int J Cancer 2004; 110: 219-224. http://dx.doi. org/10.1002/ijc.20075

[39] WOODSON K, STEWART C, BARRETT M, BHAT NK, VIRTAMO J et al. Effect of vitamin intervention on the relationship between GSTM1, smoking, and lung cancer risk among male smokers. Cancer Epidemiol Biomarkers Prev 1999; 8: 965-970.

[40] MCWILLIAMS JE, SANDERSON BJ, HARRIS EL, RICHERT-BOE KE, HENNER WD Glutathione S-transferase M1 (GSTM1) deficiency and lung cancer risk. Cancer Epidemiol Biomarkers Prev 1995; 4: 589-94.

[41] HOULSTON RS Glutathione S-Transferase M1 Status and Lung Cancer Risk : A Meta-Analysis. Cancer Epidemiol Biomarkers Prev 1999; 8: 675-682.

[42] HUNG RJ, BOFFETTA P, BROCKMOLLER J, BUTKIEWICZ $\mathrm{D}$, CASCORBI I et al. CYP1A1 and GSTM1 genetic polymorphisms and lung cancer risk in Caucasian non-smokers: a pooled analysis. Carcinogenesis 2003; 24: 875-882. http:// dx.doi.org/10.1093/carcin/bgg026

[43] CARLSTEN C, SAGOO GS, FRODSHAM AJ, BURKE W, HIGGINS JPT et al. Glutathione S-Transferase M1 (GSTM1) Polymorphisms and Lung Cancer: A Literature-based Systematic HuGE Review and Meta-Analysis. Am J Epidemiol 2008; 167: 759-774. http://dx.doi.org/10.1093/aje/kwm383
[44] HARRIS MJ, COGGAN M, LANGTON L, WILSON SR, BOARD PG Polymorphism of the Pi class glutathione S-transferase in normal populations and cancer patients. Pharmacogenetics 1998; 8: 27-31. http://dx.doi.org/10.1097/ 00008571-199802000-00004

[45] TO-FIGUERAS J, GENE M, GOMEZ-CATALAN J, PIQUE E, BORREGO N et al. Genetic polymorphism of glutathione S-transferase P1 gene and lung cancer risk. Cancer Causes Control 1999; 10: 65-70. http://dx.doi.org/10.1023/ A:1008811824890

[46] KATOH T, KANEKO S, TAKASAWA S, NAGATA N, INATOMI H. et al. Human glutathione S-transferase P1 polymorphism and susceptibility to smoking related epithelial cancer; oral, lung, gastric, colorectal and urothelial cancer. Pharmacogenetics 1999; 9: 165-169.

[47] KIHARA M, KIHARA M, NODA K Lung cancer risk of the GSTM1 null genotype is enhanced in the presence of the GSTP1 mutated genotype in male Japanese smokers. Cancer Lett 1999; 137: 53-60. http://dx.doi.org/10.1016/ $\underline{\mathrm{S} 0304-3835(98) 00337-1}$

[48] MILLER DP, LIU G, DE VIVO I, LYNCH TJ, WAIN JC et al. Combinations of the variant genotypes of GSTP1, GSTM1, and p53 are associated with an increased lung cancer risk. Cancer Res 2002; 62: 2819-2823.

[49] PERERA FP, MOONEY LA, STAMPFER M, PHILLIPS DH, BELL DA et al. Associatons between carcinogen-DNA damage, glutathione S-transferase genotypes, and risk of lung cancer in the prospective Physicians Health Cohort Study. Carcinogenesis 2002; 23: 1641-1646. http://dx.doi. org/10.1093/carcin/23.10.1641

[50] WANG Y, SPITZ MR, SCHABATH MB, ALI-OSMAN F, MATA $\mathrm{H}$ et al. Association between glutathione S-transferase p1 polymorphisms and lung cancer risk in Caucasians: a casecontrol study. Lung Cancer 2003; 40: 25-32. http://dx.doi. org/10.1016/S0169-5002(02)00537-8

[51] EL ZEIN R, ZWISCHENBERGER JB, WOOD TG, ABDELRAHMAN SZ, BREKELBAUM C et al. Combined genetic polymorphism and risk for development of lung cancer. Mutat Res 1997; 381: 189-200. http://dx.doi.org/10.1016/S0027$\underline{5107(97) 00166-8}$ 